\title{
Does Race Matter? Earnings of Visible Minority Graduates from Alberta Universities
}

\section{KATERINA MAXIMOVA}

McGill University

\section{HARVEY KRAHN}

University of Alberta

\section{ABSTRACT}

Using data from the 1997 Alberta University Graduate Survey, this study compares earnings of visible minority graduates and their non-visible minority counterparts who received degrees in 1994. The central question is whether investments in human capital in the form of Canadian postsecondary education by visible minority members and other graduates yield similar returns in the Canadian labour market. Multiple regression analysis results indicate that earnings of visible minority graduates do not differ significantly from those of other graduates, although several interesting interaction effects are observed. Overall, this study provides no evidence of racial discrimination against visible minority members who obtained their post-secondary educational credentials in Alberta. 


\section{RÉSUMÉ}

L'étude exploite les données du sondage de 1997 sur les diplômés des universités albertaines, afin de comparer la rémunération des diplômés de 1994, selon qu'ils sont membres de minorités visibles ou pas. La question centrale est de savoir si, sur le marché du travail canadien, l'investissement en capital humain représenté par des études postsecondaires rapporte les mêmes dividendes aux membres des minorités visibles qu'aux autres diplômés. Les résultats d'une analyse de régression multiple indiquent que la rémunération des diplômés appartenant à des minorités visibles ne diffère pas sensiblement de celle des autres diplômés, bien que s'observent plusieurs effets d'interaction intéressants. Dans l'ensemble, l'étude n'apporte pas de preuve d'une discrimination raciale à l'encontre des membres de minorités visibles ayant obtenu leur attestation d'études postsecondaires en Alberta.

\section{INTRODUCTION}

Post-secondary education is a powerful determinant of labour market success in the Canadian knowledge economy. But despite the high value placed on advanced education in the post-industrial Canadian labour market, post-secondary credentials obtained outside of Canada are frequently not recognized or, at best, under-valued, by Canadian employers. However, it remains unclear whether members of visible minority groups ${ }^{1}$ who obtained their educational qualifications in Canada still remain at a disadvantage. This paper focuses directly on this question because of its equity implications, but also because the potential differential treatment of visible minority groups has obvious policy implications in the context of current and projected shortages of skilled workers in Canada.

Previous research that examined labour market outcomes for ethnic and racial minorities in the Canadian labour market has been handicapped by an inability to determine the country of origin of their educational 
qualifications. Direct measures of the origin of educational credentials are rare in social surveys (and are absent in the national Census) and researchers have to measure this concept indirectly. Consequently, past studies lack conclusive evidence of whether investments in human capital in the form of Canadian post-secondary education improve the labour market position of members of visible minority groups.

Using data from the 1997 Alberta University Graduate Survey (AUGS), this paper examines whether, two and a half years after graduation, visible minority group members and their non-visible minority counterparts reported similar labour market returns to their post-secondary educational credentials. By studying only graduates from Canadian universities (in Alberta), this analysis holds constant the country from which educational credentials were obtained and, thus, completely controls for the issue of non-recognition or under-valuing of foreign educational credentials. Therefore, if racial differences in labour market outcomes are still observed in this study, non-recognition of foreign credentials cannot be used as an explanation of these differences. The conclusion then must be that some form of discrimination against members of visible minority groups (and not against their "foreign" credentials) is occurring within the Canadian labour market.

This study has important policy implications. First, for some decades now, the elimination of discriminatory labour market practices has been a policy priority for both provincial and the federal governments. In addition, as a result of the increased demands in the Canadian knowledge economy for highly skilled labour, investments in post-secondary education have come to be viewed as a social policy priority (Alexander, 1997; JeromeForget, 1997). Nonetheless, because of methodological problems in previous studies, it remains unclear whether investments in human capital in the form of Canadian post-secondary education have similar outcomes for members of visible minority groups and for others not so identified. 


\section{PREVIOUS RESEARCH}

Most studies of ethnic and racial inequality in the Canadian labour market have utilized a human capital approach to explain differences in employment outcomes of ethnic and racial groups. Previous research has shown that, for most European ethnic groups, inequalities can be explained by a lack of education and other job qualifications (Gee \& Prus, 2000; Herberg, 1990; Hou \& Balakrishnan, 1996; Kalbach \& Kalbach, 1999; Lian \& Matthews, 1998; Reitz, 1990; Stelcner \& Kyriazis, 1995). These studies demonstrate that, although investments in human capital helped European ethnic minorities overcome their initially disadvantaged position, such investments frequently failed to help members of non-white racial groups. Their labour market disadvantages persisted despite their high educational qualifications. These studies suggest that discrimination within the Canadian labour market leads to differential returns to human capital. However it remains unclear from these studies whether racial groups are discriminated against as a result of their visibility or because of non-recognition or under-valuing of their foreign educational credentials.

Persistent labour market disadvantages faced by Canadian visible minorities may be a consequence of foreign qualifications and occupational training of immigrants within this group not being recognized in the Canadian labour market (Basavarajappa \& Verma, 1985; Basran \& Zong, 1998; Hunter \& Leiper, 1993; Li, 2001; Li, 2003; Miller, 1992; Krahn, Derwing, Mulder, \& Wilkinson, 2000). While previous research has shown that completion of Canadian education by immigrants with European origins improved their disadvantaged position considerably (Baker \& Benjamin, 1994; Boyd, 1985; de Silva, 1992; Wanner, 1998; Wright \& McDade, 1992), the literature is divided over whether higher educational credentials yield increased economic returns for members of non-white groups, be they immigrants or not. Researchers have been unable to demonstrate whether the initially disadvantaged position of Canadian visible minorities could be ameliorated through investments in Canadian post-secondary education in the same way that disadvantages 
faced by previous immigrant groups of European ancestry were removed. The lack of consensus among researchers stems largely from an inability to determine the country of origin of the post-secondary credentials visible minority group members hold.

On one side of this debate, Geschwender and Guppy (1995) provide evidence that higher educational credentials do not yield additional economic payoffs for members of non-white groups born in Canada, suggesting that the visible minority disadvantage remains even for the native-born population (most of whom, presumably, obtained their education and work experience in Canada). Thus, while non-recognition of foreign educational credentials could serve as an explanation of poorer labour market outcomes for foreign-born visible minorities, it cannot explain why members of native-born visible minority groups remain disadvantaged.

Similarly, in their study of visible minority income differentials, Basavarajappa and Jones (1999) estimated earnings for four groups (visible minority and non-visible minority broken down by immigrant and Canadian-born), after controlling for human capital variables. Their analysis showed that income returns to education for visible minorities were lower regardless of their nativity status (immigrant or native-born). Thus, in these studies, the visibility of ethnic minority groups, not the source of their educational credentials, is seen as an impediment to socioeconomic achievement, even though these studies failed to control directly for the quality (i.e., source) of post-secondary credentials.

Pendakur and Pendakur (2000) reached a similar conclusion in their study of whether the quality of education (i.e., Canadian or otherwise) affects employment outcomes for visible minorities. Using Canadian Census data, they constructed a "place of schooling" measure based on place of birth and age of entry to Canada. They found substantial earnings differentials between whites and visible minorities, for both immigrants and native-born Canadians, after controlling for a number of other socioeconomic variables. The earnings gap did not subside significantly even after accounting for where post-secondary education had been obtained. 
They also observed that visible minorities with post-secondary education suffered larger penalties than those without post-secondary education. In short, even those visible minorities born and educated in Canada continued to be economically disadvantaged.

In contrast, de Silva and Doherty (1996) concluded that labour market inequality between white and non-white (minority) groups was due primarily to differences in the quality of education between the two racial groups, rather than discrimination. Their study focused only on those Census respondents who were born in Canada. Prior to controlling for differences in the quality (origin) of education, language proficiency, and work experience, they found substantial differences between visible minorities and the rest of the population. However, once controls for the quality (source) of education and other factors were introduced, the "visible minority" effect nearly disappeared.

As this quick review has shown, conflicting results obtained in these studies are due to different approaches to developing indirect measures of the source of post-secondary credentials. The studies reviewed all rely on Census data that do not directly measure this concept. ${ }^{2}$ Results from studies based on non-Census data are similarly contradictory (e.g., Christofides \& Swidinsky, 1994; Gee \& Prus, 2000; Hum \& Simpson, 1999).

An alternative way to control on the "quality" of education is to specifically study Canadian college and university graduates. Wannell and Caron (1994) used the 1992 National Graduate Survey (NGS) to analyze labour market outcomes of college and university graduates two years after they received their degrees. Their study showed that visible minorities earned slightly more (about $2 \%$ ) than did non-visible minority graduates. After further statistical controls were introduced, income differences between the two racial groups remained negligible.

However, unlike previous studies, Wannell and Caron (1994) controlled for respondents' field of study in their analysis. This is an important methodological innovation, since labour market returns are greatly influenced by one's educational discipline (Boothby, 2000; Giles \& Drewes, 2001; Lin et al., 2000). The omission of this additional focus in previous research on racial and ethnic labour market inequality is a major 
limitation since there may be significant differences across ethnic/racial groups in the types of post-secondary credentials required (e.g., Science and Engineering, perhaps, rather than Humanities and Social Sciences). If so, income differences previously attributed to racial discrimination may instead reflect differences in human capital investments (i.e., field of study).

Finally, none of the studies reviewed above controlled on study participants' current student status. Other research traditions have shown that many students in the post-secondary system, even those who have already acquired first degrees, are employed, frequently part-time, in the "student labour market" where incomes and other job rewards are limited (Krahn \& Lowe, 2002: 146). If members of visible minority groups are more likely to continue on to post-graduate education, a higher proportion might, at any given time, be employed in the "student labour market." In turn, this might lead to income differentials incorrectly being attributed to labour market discrimination.

This study attempts to address all of these critical methodological issues. It asks whether visible minority graduates from Alberta universities receive equivalent income returns to their Canadian post-secondary credentials, relative to their non-visible minority counterparts. Thus, it holds constant the quality (i.e., source) of educational credentials, thus eliminating explanations pointing to the under-valuing of foreign educational credentials. This study also controls on field of study and, furthermore, is restricted to university graduates who, when surveyed, were not enrolled in any post-secondary program. Thus, it can determine whether investments in human capital in the form of Canadian postsecondary education have a levelling effect on labour market opportunities for racial minority members.

\section{DATA AND METHODS}

Cross-sectional data from the 1997 Alberta University Graduate Survey (AUGS) are used to address the research question outlined above. This survey, designed to provide detailed information on labour market 
experiences of 1994 graduates several years after their graduation from Alberta universities, gathered a wide range of data on work arrangements, income, benefits, skill utilization, job satisfaction, and other employment outcomes (Krahn \& Lowe, 1998). ${ }^{3}$ The use of survey data collected from respondents who all graduated from universities in the same province, at the same time, reduces variability in the quality (i.e., source country) of educational credentials, as well as in the labour market context and is thus well suited to answer the research questions.

The 1997 AUGS interviewed 6,012 of the 11,743 individuals who graduated in 1994 from Alberta's four universities (University of Alberta, University of Calgary, University of Lethbridge, and Athabasca University). This translated into a response rate of $51 \%$. Graduates, whose home address was outside Canada or the USA, were omitted from the original sampling frame to ensure that the survey focused only on graduates' experiences in the North American labour market. For the purposes of this paper, this sampling strategy also served to exclude international students from the analysis. In addition, for the analyses reported in this paper, all continuing students (either full-time or part-time) were omitted. Sample members who self-identified as being of Aboriginal ancestry were also excluded from the analysis, as were those who were employed part-time, resulting in a final sub-sample of 3,680 respondents. ${ }^{4}$

The analysis of the impact of visible minority status on respondents' income uses ordinary least-squares (OLS) regression techniques, while controlling for other factors that might contribute to income differences. ${ }^{5}$ In order to test for interaction effects between predictor variables and visible minority status, separate regression equations were also calculated for visible minority respondents and for those who did not self-identify in this fashion. The differences between the un-standardized slopes (for specific predictor variables) obtained from the two models were then evaluated for statistical significance. ${ }^{6}$ 


\section{Measurement of Key Variables}

Respondents' income, the dependent variable in the analysis, is based on sample members' self-reported gross monthly earnings from all jobs. This variable has a range of values from $\$ 33$ to $\$ 24,500$.

Visible minority status, a binary variable (1=visible minority) is based on respondents' self-identification with the visible minority population. ${ }^{7}$ Almost 12 percent of the graduates in the sample identified themselves as a member of a visible minority group. This percentage is higher than the provincial average of nine percent (1991), indicating that overall visible minorities are more likely to pursue university education (Krahn \& Lowe, 1998: 18). However, it is slightly lower than the percentage for the total sample of $6,012(14 \%)$, indicating that visible minorities were also more likely to continue their post-secondary studies after they graduated in 1994.

While it might have been useful to compare returns to post-secondary education across different ethnic/racial groups, as some previous studies (e.g., Basavarajappa \& Jones, 1999; Pendakur \& Pendakur, 2000) have done, the 1997 AUGS did not ask about ethnicity. While reliance on a simple binary measure of visible minority status may limit our ability to pursue further analyses, our basic goal was to determine whether members of visible minorities, be they Asian or Black or of some other racial or ethnic origin, are discriminated against despite their Canadian educational qualifications.

The 21 field of study (FoS) categories in the AUGS were constructed out of very detailed program of study information provided about each sample member by participating universities. Table 1 shows a breakdown of the 3,680 respondents by fields of study and visible minority status. Visible minority sample members were over-represented in some fields of study and under-represented in others. At the undergraduate level, the proportion of visible minority members was higher in programs in Biological Sciences $(22.1 \%)$, Mathematical and Physical Sciences (20.5\%), Engineering (19.9\%), Other Health Professions (18.9\%), and Medicine and Dentistry (16.1\%). At the graduate level, visible minority 
Table 1

Visible Minority Status by Field of Study (21 categories)

\begin{tabular}{|c|c|c|c|c|}
\hline & $\begin{array}{c}\text { Visible } \\
\text { Minority }\end{array}$ & $\begin{array}{c}\text { Non- } \\
\text { Visible } \\
\text { Minority }\end{array}$ & Total & Total \\
\hline Field of Study & $\%$ & $\%$ & $\%$ & $\mathbf{N}$ \\
\hline Fine Arts & 7.8 & 92.2 & 2.1 & 77 \\
\hline Social Sciences & 10.4 & 89.6 & 13.6 & 500 \\
\hline Humanities & 11.4 & 88.6 & 3.1 & 114 \\
\hline Business/Commerce & 15.0 & 85.0 & 12.5 & 460 \\
\hline Education & 7.1 & 92.9 & 20.0 & 735 \\
\hline Physical Education/Kinesiology & 5.0 & 95.0 & 3.3 & 121 \\
\hline Engineering & 19.9 & 80.1 & 5.9 & 216 \\
\hline Law & 7.1 & 92.9 & 2.7 & 98 \\
\hline Medicine/Dentistry & 16.1 & 83.9 & 1.7 & 62 \\
\hline Nursing & 12.4 & 87.6 & 3.3 & 121 \\
\hline Other Health Professions & 18.9 & 81.1 & 3.9 & 143 \\
\hline Social Work & 7.5 & 92.5 & 1.4 & 53 \\
\hline Mathematics/Physical Sciences & 20.5 & 79.5 & 4.0 & 146 \\
\hline Biological Sciences & 22.1 & 77.9 & 2.3 & 86 \\
\hline Agriculture/Forestry/Earth Sciences & 6.3 & 93.7 & 3.5 & 127 \\
\hline M.A. & 4.4 & 95.6 & 2.4 & 90 \\
\hline M.Ed. & 2.8 & 97.2 & 3.9 & 143 \\
\hline M.Sc./M.Eng. & 18.8 & 81.3 & 3.9 & 144 \\
\hline MBA & 4.5 & 95.5 & 1.8 & 67 \\
\hline M.S.W./M.Nursing & 7.4 & 92.6 & 1.5 & 54 \\
\hline Ph.D. & 26.0 & 74.0 & 3.3 & 123 \\
\hline Total & 11.8 & 88.2 & 100.0 & 3,680 \\
\hline
\end{tabular}

sample members gravitated towards Master's of Science and Master's of Engineering (18.8\%) and Doctorate programs (26.0\%). It appears that members of visible minority groups tend to make post-secondary investments in fields of study that are known to yield higher monetary returns in the labour market. 
The original 21 FoS categories in the 1997 AUGS were collapsed into nine categories for the regression analyses, to ensure an adequate number of cases in each category (Table 2). In the regression equations (Table 4), field of study is operationalized as a series of binary variables. The category with the smallest income difference between visible minority and nonvisible minority sub-samples (Education/Physical Education) was omitted from the regression equations as the reference category.

Table 2

Visible Minority Status by Field of Study (9 categories)

\begin{tabular}{lcccc}
\hline & $\begin{array}{c}\text { Non- } \\
\text { Visible } \\
\text { Minority }\end{array}$ & $\begin{array}{c}\text { Visible } \\
\text { Minority }\end{array}$ & Total & Total \\
\hline Field of Study & $\boldsymbol{\%}$ & $\mathbf{\%}$ & $\boldsymbol{\%}$ & $\mathbf{N}$ \\
\hline Fine Arts/Social Sciences/Humanities & 10.3 & 89.7 & 18.8 & 691 \\
Business/Commerce & 15.0 & 85.0 & 12.5 & 460 \\
Education/Physical Education & 6.8 & 93.2 & 23.3 & 856 \\
Engineering & 19.9 & 80.1 & 5.9 & 216 \\
Law/Medicine/Dentistry & 10.6 & 89.4 & 4.3 & 160 \\
Nursing/Other Health Professions/ & & & & \\
Social Work & 14.5 & 85.5 & 8.6 & 317 \\
Natural Sciences & 15.9 & 84.1 & 9.8 & 359 \\
Master's & 8.4 & 91.6 & $\mathbf{1 3 . 5}$ & 498 \\
Doctorate & 26.0 & 74.0 & 3.3 & 123 \\
& & & & \\
\hline Total & $\mathbf{1 1 . 8}$ & $\mathbf{8 8 . 2}$ & $\mathbf{1 0 0 . 0}$ & $\mathbf{3 , 6 8 0}$ \\
& & & & \\
\hline
\end{tabular}

\section{Measurement of Other Variables}

Nine other independent variables are included as control variables in the regression analyses. Demographic characteristics include gender (male=1), marital status (married/cohabiting $=1),{ }^{8}$ dependent children or adults living in the home (yes $=1$ ), age (years), and disability status (yes $=1$ ). ${ }^{9}$ Other independent (control) variables measure whether respondents had enrolled in a post-secondary program since 1994 (yes=1) and whether they 
had any full-time work experience prior to graduation (yes=1), to control for additional human capital acquired before or after graduation, and industry (public sector $=1$; private sector $=0$ ) and self-employment (selfemployed=1), to control on possible income variations across industrial sectors and between paid employees and the self-employed.

\section{Earnings of 1994 Graduates from Alberta Universities}

Type of education (field of study) is related to income for employed university graduates (Table 3). Graduates of Law/Medicine/Dentistry, for example, earned considerably more than did Arts and Science graduates. Furthermore, we also observe income differences by visible minority status.

Although the overall income difference between visible minority graduates and their non-visible minority counterparts was only about $\$ 100$ (i.e., visible minority graduates earned $\$ 99$ less per month, on average), the earnings disadvantage of visible minorities was considerably larger in most field of study categories (Table 3 ). For example, visible minority graduates with Science degrees earned $\$ 447$ less than non-visible minority Science graduates, and the visible minority income disadvantage was $\$ 351$ for Business/Commerce graduates. In addition, visible minority sample members with graduate degrees earned less than their non-visible minority counterparts with similar advanced degrees (differences of $\$ 206$ and $\$ 598$ for Master's and doctoral degrees, respectively). ${ }^{10}$ These large negative differences were balanced by several other large positive differences. Specifically, visible minority graduates from Law, Medicine, and Dentistry reported earning $\$ 826$ per month more than did non-visible minority graduates from these professional faculties. Similarly, the (positive) income difference for graduates of Nursing, Other Health Professions, and Social Work programs was $\$ 198$.

Given that the overall income difference was quite small (Table 3), it is not surprising that the effect of visible minority status on earnings was no longer statistically significant after controlling for the effects of other predictor variables (Table 4, Column 1). Instead, type of education 
Table 3

Average Monthly Income from All Jobs by Field of Study and Visible Minority Status

\begin{tabular}{|c|c|c|c|c|c|c|}
\hline & & Visible & rity & Non-Visil & linority & Mean Difference \\
\hline & Field of Study & Mean (\$) & $\mathbf{N}$ & Mean $(\$)$ & $\mathbf{N}$ & $\$$ \\
\hline & Fine Arts/Social Sciences/Humanities & 2,253 & 62 & 2,533 & 556 & $-280 *$ \\
\hline & Business/Commerce & 2,959 & 60 & 3,310 & 357 & $-351 *$ \\
\hline & Education/Physical Education & 2,643 & 50 & 2,739 & 736 & -96 \\
\hline$\frac{6}{3}$ & Engineering & 3,553 & 42 & 3,814 & 153 & -262 \\
\hline$\Omega$ & Law/Medicine/Dentistry & 5,672 & 16 & 4,846 & 125 & 826 \\
\hline$\stackrel{2}{5}$ & Nursing/Other Health Professions/Social & & & & & \\
\hline : & Work & 3,645 & 39 & 3,447 & 252 & 198 \\
\hline $\bar{\Xi}$ & Natural Sciences & 2,817 & 49 & 3,264 & 270 & $-447 *$ \\
\hline హ. & Master's & 4,148 & 35 & 4,354 & 407 & -206 \\
\hline 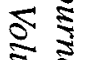 & Doctorate & 3,535 & 31 & 4,133 & 83 & $-598 *$ \\
\hline$\stackrel{0}{\infty}$ & Total & 3,188 & 384 & $\mathbf{3 , 2 8 7}$ & 2,939 & -99 \\
\hline 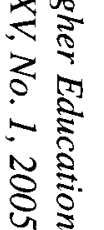 & * Difference is statistically significant (t-tes & $<0.05)$ & & & & \\
\hline
\end{tabular}


(i.e., the series of field of study binary variables) was the best predictor of monthly income. Respondents with degrees in Fine Arts, Humanities and Social Sciences were the most disadvantaged in terms of income (compared to the reference category, respondents with Education and Physical Education degrees). Conversely, those with degrees in Law, Medicine, and Dentistry, as well as respondents with Master's degrees, fared much better than graduates from Education and Physical Education programs. Incomes of sample members from all other fields of study were also substantially higher than earnings of Education and Physical Education graduates.

Gender, marital status, age, additional education since 1994, prior work experience, and self-employment also had significant positive effects on respondents' earnings. Disability status had a small negative effect. However, our concern in this analysis is with the impact of visible minority status and, as already noted, this effect is small and nonsignificant $($ Beta $=-0.024)$.

Table 4 also examines the effects on income of all the other predictor variables separately for visible minority and non-visible minority graduates. Looking first at fields of study, the differences between slope coefficients estimated in the two models (Columns 2 and 3) reveal that Engineering degrees, Law, Medicine and Dentistry degrees, and Nursing, Other Health Professions, and Social Work degrees had a more positive effect on income for visible minorities than they did for non-visible minority graduates. For all other fields of study, the pattern was reversed, with visible minority graduates earning less, other things being equal, than their non-visible minority counterparts with similar degrees.

However, the interaction effect (i.e., the difference between slopes) was only significant for graduates from Law, Medicine, and Dentistry programs, indicating that, relative to the Education and Physical Education category, visible minority graduates from these programs earned significantly more than did their non-visible minority counterparts who graduated from the same programs. Thus, visible minority graduates from Law, Medicine, and Dentistry programs appeared to benefit financially from their degrees much more than did non-visible minority graduates from the same programs. 
Table 4

Net Effects of Visible Minority Status and Other Predictor Variables on Monthly Income (full model and by visible minority status)

\begin{tabular}{|c|c|c|c|}
\hline & Full Sample & $\begin{array}{l}\text { Visible } \\
\text { Minority }\end{array}$ & $\begin{array}{l}\text { Non- } \\
\text { Visible } \\
\text { Minority }\end{array}$ \\
\hline Independent Variables & Beta & $\mathbf{b}$ & b \\
\hline $\begin{array}{l}\text { Visible Minority Status } \\
\text { Visible minority }=1 \\
\text { Gender }\end{array}$ & -0.024 & $* * *$ & $* * *$ \\
\hline $\begin{array}{l}\text { Male }=1 \\
\text { Marital Status }\end{array}$ & $0.171 *$ & $170.70^{\prime}$ & $584.01 * 1$ \\
\hline $\begin{array}{l}\text { Married or have partner }=1 \\
\text { Dependents }\end{array}$ & $0.059^{*}$ & 125.89 & $192.41 *$ \\
\hline $\begin{array}{l}\text { Have dependent children or adults living } \\
\text { with you }=1\end{array}$ & 0.011 & -166.14 & 79.27 \\
\hline $\begin{array}{l}\text { Age } \\
\text { Disability Status }\end{array}$ & $0.112 *$ & $-1.68^{\prime}$ & $25.93^{* 1}$ \\
\hline $\begin{array}{l}\text { Have disability = } 1 \\
\text { Post-Graduation enrolment since } 1994\end{array}$ & $-0.041^{*}$ & -167.01 & $-422.60 *$ \\
\hline $\begin{array}{l}\text { Have been enrolled in post-secondary } \\
\text { program }=1 \\
\text { Prior Work Experience }\end{array}$ & -0.028 & -2.57 & $-126.87 *$ \\
\hline $\begin{array}{l}\text { Worked full-time before graduating in } \\
1994=1 \\
\text { Industry Type }\end{array}$ & $0.048 *$ & $779.78^{* 1}$ & $75.67^{1}$ \\
\hline $\begin{array}{l}\text { Public Sector }=1 \\
\text { Self-employment }\end{array}$ & 0.003 & -154.72 & 19.40 \\
\hline $\begin{array}{l}\text { Self-employed }=1 \\
\text { Field of Study } \\
\text { Fine Arts/Social }\end{array}$ & $0.14 *$ & $818.81 *$ & $765.18 *$ \\
\hline Sciences/Humanities & $-0.048 *$ & -494.22 & $-177.63 *$ \\
\hline Business/Commerce & $0.095 *$ & 142.06 & $475.95 *$ \\
\hline Engineering & $0.134 *$ & $925.51 *$ & $904.90 *$ \\
\hline $\begin{array}{l}\text { Law/Medicine/Dentistry } \\
\text { Nursing/Other Health }\end{array}$ & $0.242 *$ & $2,691.92 * 1$ & $1,804.55 *$ \\
\hline Professions/Social Work & $0.145 *$ & $1,155.98 *$ & $762.35 *$ \\
\hline Natural Sciences & $0.078 *$ & 215.01 & $434.02 *$ \\
\hline Master's & $0.251 *$ & $1,134.70^{*}$ & $1,175.10^{*}$ \\
\hline Doctorate & $0.083 *$ & $637.04 *$ & $828.45 *$ \\
\hline $\begin{array}{l}\text { Constant } \\
R^{2} \\
\mathrm{~N}\end{array}$ & $\begin{array}{c}1,693.930 * \\
0.270 \\
3,306.000\end{array}$ & $\begin{array}{c}2,403.67^{*} \\
0.35 \\
383.00\end{array}$ & $\begin{array}{c}1,625.89 * \\
0.26 \\
2,923.00\end{array}$ \\
\hline
\end{tabular}

* Coefficient is statistically significant (t-test; $p<0.01$ ).

' Difference between slopes (i.e., between columns 2 and 3 ) is statistically significant (t-test; $p<0.05$ ). 
Substantial differences between the visible and non-visible minority sub-samples were also observed for the effects of gender, age, and prior work experience on respondents' income. The interaction effect of gender and visible minority status indicates that non-visible minority males have higher incomes compared to visible minority males, controlling on all the other variables in the equation. While being older was associated with higher income for non-visible minority graduates, it had a negative effect on earnings of visible minority graduates. Finally, having full-time work experience was much more beneficial, in terms of income, for visible minority graduates than for all other graduates.

\section{DISCUSSION}

Overall, visible minority status did not have a significant effect on respondents' earnings after other factors were taken into account. Rather, respondents' human capital characteristics substantially influenced their monthly incomes. The most important effect was traced to different types of university degrees. In other words, field of study was a strong predictor of respondents' earnings. But limited evidence of differential labour market rewards was found when comparing visible minority graduates and their non-visible minority counterparts with the same types of university degrees. The only exception was for graduates from Law, Medicine, and Dentistry programs; visible minority respondents from these programs had substantially higher earnings than did their non-visible minority counterparts.

This finding may reflect differences in cultural and social capital between visible minority members and other graduates. In other words, the higher earnings of racial minorities with professional degrees in Law, Medicine, and Dentistry may be a result of their stronger social networks (i.e., greater social capital). The preference of racial minority clients for dealing with a lawyer, a family physician, or a dentist who is also a visible minority member may be responsible for higher financial returns for visible minority graduates with professional degrees. Unfortunately, the 1997 AUGS did not include measures of cultural and social capital, so we cannot test this explanation.

The Canadian Journal of Higher Education

Volume XXXV, No. 1, 2005 
It is also possible that the higher earnings of these particular graduates may be a result of their stronger work ethic, which is often characteristic of first- and second-generation immigrants. Many graduates from these professional fields are self-employed and in a position where longer hours can actually translate into higher incomes (as compared to most paid employment where income is not a function of hours worked). Thus, for visible minority professionals, self-employment may have offered a better opportunity to benefit from their strong work ethic, thus resulting in higher earnings.

Prior work experience (another measure of human capital) also significantly increased respondents' incomes. In addition, significant differences in labour market returns to such experience were observed between visible minority and non-visible minority graduates. Visible minority graduates were able to benefit much more from the work experience they obtained prior to their graduation from university than were other graduates with such experience. Thus, while labour market returns to university degrees held by visible minority graduates were on par with other graduates, previous work experience of visible minority graduates received more recognition by employers and resulted in higher earnings. A convincing explanation of this finding is, unfortunately, not immediately apparent.

Summing up, the non-effect of visible minority status indicates that visible minority graduates experienced no significant labour market disadvantages on the basis of their visibility alone. Rather, as indicated by significant interaction effects, they were deprived of labour market rewards on the basis of other factors. Visible minority male graduates received significantly lower incomes than did non-visible minority males. If visible minority graduates were older, their incomes were also significantly lower than those of their non-visible minority counterparts. Thus, although visible minority graduates from Alberta universities experience no direct income disadvantage, they were less likely to receive the additional earnings that gender (being a male) and age (being older) typically provide. This finding is consistent with previous research that found substantial gendered income differentials between racial groups 
(Pendakur \& Pendakur, 2000; Pendakur \& Pendakur, 2002). However, the underlying reasons why racial minorities are deprived of labour market rewards on the basis of factors such as gender and age require additional research. These findings are particularly interesting since recent research provides no evidence of gender differences in labour market outcomes among recent university graduates (Abbott et al., 1999).

\section{CONCLUSIONS}

This study provides a clear answer to the fundamental question of whether the earnings of members of visible minority groups who possess Canadian post-secondary educational credentials are commensurate with their qualifications. Visible minority members who obtained their postsecondary educational qualifications in Canada, or more precisely in Alberta, received labour market returns similar to those of their non-visible minority counterparts. Therefore, the disadvantaged position of racial minorities in the Canadian labour market observed in previous research was likely due to non-recognition of their educational credentials obtained in their respective countries of origin.

This study shows that post-secondary degrees from Alberta universities held by visible minority graduates appeared to have the same "value" in the Canadian labour market as do degrees held by non-visible minority graduates. It remains possible, of course, that the strong economy in Alberta in the late 1990s shaped these survey findings to some extent, and that discrimination against visible minority university graduates might more likely surface in times and places where unemployment rates are higher. Further research on this possible interaction effect would be useful. However, to the extent that Alberta findings can be extrapolated to the nation as a whole, this study suggests that, among contemporary university-educated labour force participants, racial groups that have traditionally been disadvantaged in the Canadian labour market now have relatively equal employment opportunities.

This finding is supportive of public policy initiatives that view investments in human capital as a basis for reducing labour market 
inequalities. It also suggests that policy efforts should be directed toward other segments of the visible minority population, namely those without Canadian educational qualifications. Recognition of foreign credentials should become a policy priority. In addition, addressing the underrepresentation of Aboriginal Canadians in the higher education system should be high on the policy agenda. The very fact that the current study could not look at Aboriginal respondents due to their small number in the AUGS sample is a reflection of their severe under-representation in the post-secondary system.

Results of this study, particularly the finding of higher earnings of visible minority graduates with professional degrees in Law, Medicine, and Dentistry, cannot be fully explained without referencing the effects of cultural and social capital that graduates from different racial backgrounds might possess. The notion of social capital, in particular, has been used to explain labour market inequalities (Bourdieu, 1986; Loury, 1977; Portes, 1998; Wial, 1991). Although social capital theory was not utilized at the outset as a theoretical framework for this study, the findings suggest that it can be usefully adopted as an additional explanation of income differentials. Such an explanation would be consistent with the emerging body of literature on social capital that underscores the importance of social ties for social and economic success of Canadian ethnic minorities (Gold \& Kibria, 1993; Lamba, 2003; Lamba \& Krahn, 2003; Li, 2004). Further research on this important aspect of labour market inequalities would clearly be useful.

We must note that we cannot tell whether the non-effect of visible minority status on earnings indicates that racial minorities are no longer discriminated against in the Canadian labour market because of effective employment equity legislation, because of skilled labour market shortages, or due to other factors. Further research directly addressing the question of why things appear to have changed would be useful.

In fact, the small income disadvantages of visible minority status observed within almost all fields of study may be a preliminary sign of subtle discrimination. Respondents in the 1997 AUGS were interviewed two and a half years after graduation from Alberta universities. Assessing their 
labour market outcomes, and income in particular, so soon after graduation may not allow a sufficient time span to capture income differences across racial groups that could emerge over time. However, while these findings may be evidence of initial labour market disadvantages of visible minority university graduates, the differences might also become less pronounced as these graduates progress in their careers. A follow-up study of university graduates, five or ten years after graduation, could shed further light on their labour market experiences as their careers progress.

A few final cautions about over-generalization from our findings are in order. While it would have been useful to look at the labour market experiences of specific racial/ethnic groups, the 1997 AUGS data did not allow us to do so. Only a single binary measure of self-reported visible minority status was included in the original questionnaire. Consequently, even though our analysis clearly shows that visible minority status does not have a significant effect on earnings, it remains possible that some specific ethnic/racial groups do encounter discrimination within the Canadian labour market, even though their post-secondary credentials are Canadian in origin. Future research will have to examine this possibility.

Finally, results of this analysis may not hold for other segments of the visible minority population, such as college or vocational school graduates. Studies that assess the possibility of differential labour market outcomes for visible minority and non-visible minority graduates from these sectors of the post-secondary system are needed in order to fully understand patterns of labour market discrimination against racial minorities in Canada. 


\section{Notes}

' The term "visible minority" refers to persons who are non-white, nonCaucasian, and non-Aboriginal. The visible minority population includes Blacks, Chinese, Filipinos, Japanese, Koreans, Latin American, other Pacific Islanders, South Asians, South East Asians, West Asians, and Arabs (Kelly, 1995: 3).

${ }^{2}$ In addition, the Census definition of ethnicity has been altered several times over the years (Pendakur \& Mata, 2000) and this may have further contributed to contradictory results.

${ }^{3}$ See Krahn and Lowe (1998) for a detailed description of the survey design and methodology. The questionnaire content and research procedures for this study were approved by a Research Ethics Committee at the University of Alberta.

${ }^{4}$ As noted earlier, continuing students ( $\mathrm{n}=1,408$ in this sample) are likely to be employed in "student labour market" jobs that are substantially different from the type of employment individuals seek after graduation (Krahn \& Lowe, 2002: 146). Previous research has shown that employment outcomes of graduates of Aboriginal ancestry ( $n=83$ in this study) are significantly different from those of other graduates (Armstrong, 1999; de Silva, 1999). In addition, it is important to control on the number of hours worked when studying income returns to human capital investments.

${ }^{5} \mathrm{We}$ also repeated the analysis using logged income. These regression results were very similar to those reported in this paper. We chose to present the non-logged results because the effects of the various predictor variables can be interpreted in real dollar amounts.

${ }^{6}$ The following formula was used to determine whether differences between slopes were statistically significant:

$$
t=\frac{b_{1}-b_{2}}{\sqrt{S E_{1}^{2}+S E_{2}^{2}}}
$$

where $b_{1}$ is a regression slope for visible minority graduates and $b_{2}$ is a regression slope for non-visible minority graduates, and $S E_{l}$ is a standard error of the slope for visible minority graduates and $S E_{2}$ is a standard error of the slope for nonvisible minority graduates. The interaction effect was considered to be statistically significant if the obtained $t$-value was greater than $1.96(\mathrm{p}<0.05)$. 
${ }^{7}$ Sample members were asked: "Do you consider yourself to be a member of a visible minority group? (Members of visible minorities are persons who are non-Caucasian in race or non-white in colour. Examples of visible minority groups are: Black, Asian, Middle Eastern, etc.)" We believe that this self-identification measure has greater validity than measures previously utilized by other researchers (e.g., country of birth, mother tongue, language spoken at home). For example, one could be White and born in Kenya, or a Japanese respondent could speak English at home. Furthermore, these other measures do not take into account how people perceive themselves in relation to others.

${ }^{8}$ Marital status was included as a predictor in the regression equations because it could have an affect on labour force behaviour. Having a spouse/ partner may allow respondents to wait for better, higher-paying job opportunities or, alternatively, may increase the urgency to find and accept employment.

${ }^{9}$ Sample members were asked: "Do you consider yourself to have a disability that may disadvantage you in employment?"

${ }^{10}$ Wannell and Caron (1994) found an overall income advantage for visible minority university graduates, but also showed that earnings of visible minority graduates with Master's and Doctorate degrees were lower than earnings of other graduates with similar degrees.

\section{Acknowledgements:}

The study on which this paper is based was funded by Alberta Advanced Education and Career Development (AAECD), and coordinated by a Steering Committee comprised of AAECD officials and representatives from Alberta's four universities. The survey data were collected by the Population Research Laboratory, University of Alberta. Useful comments on earlier drafts of this paper from Graham S. Lowe and Lynn Duncan, and from three anonymous reviewers for this journal, are gratefully acknowledged. 


\section{References}

Abbott, M., Finnie, R., \& Wannell, T. (1999). Gender differences in earnings growth of recent university graduates in Canada: Empirical evidence from the National Graduates Surveys. Research Paper R-00-1-2E. Ottawa: Human Resources Development Canada and Statistics Canada.

Alexander, T.J. (1997). Human capital investment: Building the 'knowledge economy.' Policy Options, 18(6), 5-8.

Armstrong, R. (1999). Mapping the conditions of First Nations communities. Canadian Social Trends, Winter, 14-18.

Baker, M., \& Benjamin, D. (1994). The performance of immigrants in the Canadian labour market. Journal of Labour Economics, 12(3), 369-405.

Basavarajappa, K.G., \& Jones, F. 1999. Visible minority income differences. In S.S. Halli \& L. Driedger (Eds.), Immigrant Canada: Demographic, economic, and social challenges (pp. 230-257). Toronto: University of Toronto Press.

Basavarajappa, K.G., \& Verma, R.B.P. (1985). Asian immigrants in Canada: Some findings from 1981 Census. International Migration, 23(1), 97-121.

Basran, G.S., \& Zong, L. (1998). Devaluation of foreign credentials as perceived by visible minority professional immigrants. Canadian Ethnic Studies, 30, 6-23.

Boothby, D. (2000). Earnings differences by detailed field of study of university graduates. Research Paper R-00-1-5E. Ottawa: Human Resources Development Canada and Statistics Canada.

Bourdieu, P. (1986). The forms of capital. In J.G. Richardson (Ed.), Handbook of theory and research for the sociology of education (pp. 241-258). New York: Greenwood Press.

Boyd, M. (1985). Immigration and occupational attainment in Canada. In M. Boyd, J. Goyder, F.E. Jones, H.A. McRoberts, P.C. Pineo, \& J. Porter (Eds.), Ascription and achievement: Studies in mobility and status attainment in Canada (pp. 393-445). Ottawa: Carleton University Press.

Christofides, L.N., \& Swidinsky, R. (1994). Wage determination by gender and visible minority status: Evidence from the 1989 LMAS. Canadian Public Policy, 20(1), 34-51.

Clark, W. (1999). Search for success: Finding work after graduation. Canadian Social Trends, Summer, 10-14. Statistics Canada, Catalogue No. 11-008.

de Silva, A. (1992). Earnings of immigrants: A comparative analysis. Ottawa: Economic Council of Canada. 
de Silva, A. (1999). Wage discrimination against natives. Canadian Public Policy, $25(1), 65-83$.

de Silva, A., \& Doherty, C. (1996). Discrimination against visible minority men. Working Paper W-96-6E. Hull: Human Resources Development Canada.

Gee, E.M., \& Prus, S.G. (2000). Income inequality in Canada: A 'racial divide.' In M.A. Kalbach \& W.E. Kalbach (Eds.), Perspectives on ethnicity in Canada: A reader (pp. 238-256). Toronto: Harcourt Canada.

Geschwender, J.A., \& Guppy, N. (1995). Ethnicity, educational attainment, and earned income among Canadian-born men and women. Canadian Ethnic Studies, 27(1), 67-83.

Giles, P., \& Drewes, T. (2001). Liberal arts degrees and the labour market. Perspectives on Labour and Income, Autumn, 1-7.

Gold, S.J., \& Kibria, N. (1993). Vietnamese refugees and blocked mobility. Asian and Pacific Migration Journal, 2(1), 27-55.

Herberg, E.N. (1990). The ethno-racial socioeconomic hierarchy in Canada: Theory and analysis of the new vertical mosaic. International Journal of Comparative Sociology, 31(3-4), 206-221.

Hou, F., \& Balakrishnan, T.R. (1996). The integration of visible minorities in contemporary Canadian society. Canadian Journal of Sociology, 21(3), 307-326.

Hum, D., \& Simpson, W. (1999). Wage opportunities for visible minorities in Canada. Canadian Public Policy, 25(3), 379-394.

Hunter, A.A., \& Leiper, J.M. (1993). On formal education, skills and earnings: The role of educational certificates in earnings determination. Canadian Journal of Sociology, 18(1), 21-42.

Jerome-Forget, M. (1997). Investing in human capital. Policy Options, 18(6), 1.

Kalbach, M.A., \& Kalbach, W.E. (1999). Demographic overview of ethnic origin groups in Canada. In P. Li (Ed.), Race and ethnic relations (2nd ed.) (pp. 21-51). Toronto: Oxford University Press.

Kelly, K. (1995). Visible minorities: A diverse group. Canadian Social Trends, Summer, 3-8.

Krahn, H., Derwing, T., Mulder, M., \& Wilkinson, L. (2000). Educated and underemployed: Refugee integration into the Canadian labour market. Journal of International Migration and Integration, 1(1), 59-84.

Krahn, H., \& Lowe, G.S. (1998). 1997 Alberta graduate survey: Labour market and educational experiences of 1994 university graduates. Edmonton: AB: Population Research Laboratory, University of Alberta. 
Krahn, H., \& Lowe, G.S. (2002). Work, industry, and Canadian society (4th ed.). Scarborough, ON: Thomson Nelson.

Lamba, N. (2003). The employment experiences of Canadian refugees: Measuring the impact of human and social capital on quality of employment. Canadian Review of Sociology and Anthropology, 40(1), 45-64.

Lamba, N., \& Krahn, H. (2003). Social capital and refugee resettlement: The social networks of refugees in Canada. Journal of International Migration and Integration, 4(3), 335-360.

Li, P. (2001). The market worth of immigrants' educational credentials. Canadian Public Policy, 27(1), 23-38.

Li, P. (2003). Destination Canada: Immigration debates and issues. Toronto: Wall and Thompson.

Li, P. (2004). Social capital and economic outcomes for immigrants and ethnic minorities. Journal of International Migration and Integration, 5(2), 171-190.

Lian, J.Z., \& Matthews, D.R. (1998). Does the vertical mosaic still exist? Ethnicity and income in Canada, 1991. Canadian Review of Sociology and Anthropology, 35(4), 461-481.

Lin, Z., Sweet, R., Anisef, P., \& Scheutze, H. (2000). Consequences and policy implications for university students who have chosen liberal or vocational education: Labour market outcomes and employability skills. Ottawa: Human Resources Development Canada and Statistics Canada. Research Paper R-00-2-3E.

Loury, G.C. (1977). A dynamic theory of racial income differences. In P.A. Wallace \& A.M. LaMond (Eds.), Women, minorities, and employment discrimination (pp. 153-186). Toronto: D.C. Heath and Company.

Miller, P.W. (1992). The earnings of Asian male immigrants in the Canadian labor market. International Migration Review, 27(4), 1222-1247.

Pendakur, R., \& Mata, F. (2000). Patterns of ethnic identification and the 'Canadian' response. In M.A. Kalbach \& W.E. Kalbach (Eds.), Perspectives on ethnicity in Canada: A reader (pp. 73-87). Toronto: Harcourt Canada.

Pendakur, K., \& Pendakur, R. (2000). Ethnicity and earnings. In R. Pendakur (Ed.), Immigrants and the labour force: Policy, regulation, and impact (pp. 159-191). Montreal \& Kingston: McGill-Queen's University Press.

Pendakur, K., \& Pendakur, R. (2002). Colour my world: Have earnings gaps for Canadian-born ethnic minorities changed over time? Canadian Public Policy, $28(4), 489-511$. 
Portes, A. (1998). Social capital: Its origins and applications in modern sociology. Annual Review of Sociology, 24, 1-24.

Reitz, J.G. (1990). Ethnic concentrations in labour markets and their implications for ethnic inequality. In R. Breton, W.W. Isajiw, W.E. Kalbach, \& J.G. Reitz (Eds.), Ethnic identity and equality: Varieties of experience in a Canadian city (pp. 135-195). Toronto: University of Toronto Press.

Stelcner, M., \& Kyriazis, N. (1995). An empirical analysis of earnings among ethnic groups in Canada. International Journal of Contemporary Sociology, 32(1), 41-79.

Wannell, T., \& Caron, N. (1994). A look at employment-equity groups among recent post-secondary graduates: Visible minorities, Aboriginal Peoples and the activity limited. Ottawa: Analytical Studies Branch, Statistics Canada. Research Paper Series No. 69 (Cat. No. 11F0019MPE).

Wanner, R.A. (1998). Prejudice, profit, or productivity: Explaining returns to human capital among male immigrants to Canada. Canadian Ethnic Studies, $30(3), 24-55$.

Wial, H. (1991). Getting a good job: Mobility in a segmented labour market. Industrial Relations, 30(3), 396-416.

Wright, R.E., \& McDade, K. (1992). Barriers to the recognition of the credentials of immigrants in Canada: An analysis using census data. Ottawa: Department of the Secretary of State of Canada. 